\title{
Front Matter: Volume 9077
}

, "Front Matter: Volume 9077," Proc. SPIE 9077, Radar Sensor Technology XVIII, 907701 (9 June 2014); doi: 10.1117/12.2072102

SPIE. Event: SPIE Defense + Security, 2014, Baltimore, MD, United States 


\title{
PROCEEDINGS OF SPIE
}

\section{Radar Sensor Technology XVIII}

\author{
Kenneth I. Ranney \\ Armin Doerry \\ Editors
}

\section{5-7 May 2014 \\ Baltimore, Maryland, United States}

Sponsored and Published by

SPIE 
The papers included in this volume were part of the technical conference cited on the cover and title page. Papers were selected and subject to review by the editors and conference program committee. Some conference presentations may not be available for publication. The papers published in these proceedings reflect the work and thoughts of the authors and are published herein as submitted. The publisher is not responsible for the validity of the information or for any outcomes resulting from reliance thereon.

Please use the following format to cite material from this book:

Author(s), "Title of Paper," in Radar Sensor Technology XVIII, edited by Kenneth I. Ranney,

Armin Doerry, Proceedings of SPIE Vol. 9077 (SPIE, Bellingham, WA, 2014) Article CID Number.

ISSN: 0277-786X

ISBN: 9781628410143

Published by

SPIE

P.O. Box 10, Bellingham, Washington 98227-0010 USA

Telephone +1 3606763290 (Pacific Time) · Fax +1 3606471445

SPIE.org

Copyright (C) 2014, Society of Photo-Optical Instrumentation Engineers.

Copying of material in this book for internal or personal use, or for the internal or personal use of specific clients, beyond the fair use provisions granted by the U.S. Copyright Law is authorized by SPIE subject to payment of copying fees. The Transactional Reporting Service base fee for this volume is $\$ 18.00$ per article (or portion thereof), which should be paid directly to the Copyright Clearance Center (CCC), 222 Rosewood Drive, Danvers, MA 01923. Payment may also be made electronically through CCC Online at copyright.com. Other copying for republication, resale, advertising or promotion, or any form of systematic or multiple reproduction of any material in this book is prohibited except with permission in writing from the publisher. The CCC fee code is 0277-786X/14/\$18.00.

Printed in the United States of America.

Publication of record for individual papers is online in the SPIE Digital Library.

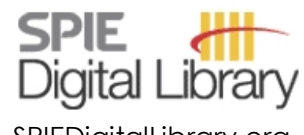

SPIEDigitalLibrary.org

Paper Numbering: Proceedings of SPIE follow an e-First publication model, with papers published first online and then in print and on CD-ROM. Papers are published as they are submitted and meet publication criteria. A unique, consistent, permanent citation identifier (CID) number is assigned to each article at the time of the first publication. Utilization of CIDs allows articles to be fully citable as soon as they are published online, and connects the same identifier to all online, print, and electronic versions of the publication. SPIE uses a six-digit CID article numbering system in which:

- The first four digits correspond to the SPIE volume number.

- The last two digits indicate publication order within the volume using a Base 36 numbering

system employing both numerals and letters. These two-number sets start with 00, 01, 02, 03, 04,

$05,06,07,08,09,0 A, 0 B \ldots$. OZ, followed by 10-1Z, 20-2Z, etc.

The CID Number appears on each page of the manuscript. The complete citation is used on the first page, and an abbreviated version on subsequent pages. Numbers in the index correspond to the last two digits of the six-digit CID Number. 


\section{Contents}

ix Conference Committee

\section{SESSION 1 PHENOMENOLOGY AND TECHNOLOGY}

907702 FPGA architectures for electronically scanned wide-band RF beams using 3D FIR/IIR digital filters for rectangular array aperture receivers [9077-1]

S. Wijayaratna, A. Madanayake, B. D. Beall, Univ. of Akron (United States); L. T. Bruton, Univ. of Calgary (Canada)

907703 Automated cancellation of harmonics using feed-forward filter reflection for radar transmitter linearization [9077-2]

K. A. Gallagher, The Pennsylvania State Univ. (United States); G. J. Mazzaro, The Citadel (United States); R. M. Narayanan, The Pennsylvania State Univ. (United States);

K. D. Sherbondy, A. F. Martone, U.S. Army Research Lab. (United States)

907704 Characterization of carbon fiber composite materials for RF applications [9077-3]

E. J. Riley, E. H. Lenzing, R. M. Narayanan, The Pennsylvania State Univ. (United States)

907705 Tapered slot antenna design for vehicular GPR applications [9077-4]

E. BIçak, TUBITAK BILGEM (Turkey); K. Yeğin, TUBITAK BILGEM (Turkey) and Yeditepe Univ.

(Turkey); H. Nazlı, M. Dağ, TUBITAK BILGEM (Turkey)

\section{SESSION 2 PROGRAMS AND SYSTEMS}

907706 Multi-mission autonomous synthetic aperture radar [9077-5]

T. J. Walls, M. L. Wilson, U.S. Naval Research Lab. (United States); D. Madsen, M. Jensen,

S. Sullivan, Space Dynamics Lab. (United States); M. Addario, I. Hally, SRC Inc. (United States)

907707 Compressive wideband microwave radar holography [9077-7]

S. A. Wilson, R. M. Narayanan, The Pennsylvania State Univ. (United States)

907708 Design and performance of an ultra-wideband stepped-frequency radar with precise frequency control for landmine and IED detection [9077-8]

B. R. Phelan, The Pennsylvania State Univ. (United States); K. D. Sherbondy, K. I. Ranney, U.S. Army Research Lab. (United States); R. M. Narayanan, The Pennsylvania State Univ. (United States)

\section{SESSION 3 ALGORITHMS AND PROCESSING I}

907709 Arbitrary scene simulation for synthetic aperture radar [9077-10]

C. Musgrove, R. Naething, J. Schilling, Sandia National Labs. (United States) 
9077 OA Improving target position and velocity estimation for air-to-air radar [9077-11]

G. Liu, N. Askar, General Atomics Aeronautical Systems, Inc. (United States)

9077 OB Identification of maritime target objects from high resolution TerraSAR-X data using SAR simulation [9077-12]

H. Anglberger, T. Kempf, M. Hager, R. Speck, H. Suess, Deutsches Zentrum für Luft- und Raumfahrt e.V. (Germany)

9077 OC A complete ensemble empirical mode decomposition for GPR signal time-frequency analysis [9077-13]

J. Li, Delaware State Univ. (United States) and Jilin Univ. (China); L. Chen, Jilin Univ. (China);

S. Xia, P. XU, F. Liu, Delaware State Univ. (United States)

9077 OD Spectrum sensing techniques for nonlinear radar [9077-66]

A. Martone, K. Ranney, U.S. Army Research Lab. (United States); G. Mazzaro, The Citadel (United States); D. McNamara, J. Silvious, K. Sherbondy, U.S. Army Research Lab. (United

States); K. Gallagher, R. Narayanan, The Pennsylvania State Univ. (United States)

SESSION 4 ALGORITHMS AND PROCESSING II

9077 OE Radar signatures of indoor clutter for through-the-wall radar applications [9077-15]

T. D. Bufler, R. M. Narayanan, The Pennsylvania State Univ. (United States); T. Dogaru, U.S. Army Research Lab. (United States)

9077 OF Textural feature selection for enhanced detection of stationary humans in through-the-wall radar imagery [9077-16]

A. Chaddad, F. Ahmad, M. G. Amin, Villanova Univ. (United States); P. Sévigny, D. DiFilippo, Defence Research and Development Canada (Canada)

9077 OG High-order approximation compact schemes for forward subsurface scattering problems [9077-17]

Y. A. Gryazin, Idaho State Univ. (United States)

SESSION 5 NOISE AND LOW-PROBABILITY OF INTERCEPT RADAR

$9077 \mathrm{OH} \quad$ GNSS-based passive airborne radar: hybrid-aperture sensing and airborne test plans [9077-18]

R. Silver, H. Suarez, Y. Zhang, Y.-R. Huang, M. Tyler, Univ. of Oklahoma (United States)

9077 ol An optimized universal hardware-based adaptive correlation receiver architecture [9077-19]

Z. Zhu, H. Suarez, Y. Zhang, S. Wang, The Univ. of Oklahoma (United States)

9077 0J Ultra-wideband noise radar imaging of cylindrical PEC objects using diffraction tomography [9077-20]

H. J. Shin, R. M. Narayanan, The Pennsylvania State Univ. (United States); M. Rangaswamy, Air Force Research Lab. (United States) 
9077 OK SAR image quality using advanced pulse compression noise (APCN) [9077-21] M. A. Govoni, R. A. Elwell, U.S. Army CERDEC Intelligence and Information Warfare Directorate (United States)

9077 OM Super-resolution processing for multi-functional LPI waveforms [9077-23]

Z. Li, Y. Zhang, S. Wang, J. Cai, The Univ. of Oklahoma (United States)

9077 ON A combined STAP/DPCA algorithm for enhanced endoclutter target detection [9077-24] T. Medl, General Atomics Aeronautical Systems, Inc. (United States)

$907700 \quad$ Image reconstruction and compressive sensing in MIMO radar [9077-26] B. Sun, BeiHang Univ. (China); J. Lopez, Univ. of Houston (United States); Z. Qiao, The Univ. of Texas-Pan American (United States)

$90770 Q \quad$ Indoor experimental facility for airborne synthetic aperture radar (SAR) configurations: railSAR [9077-28]

G. Kirose, U.S. Army Research Lab. (United States); B. R. Phelan, The Pennsylvania State Univ. (United States); K. D. Sherbondy, K. I. Ranney, F. Koenig, U.S. Army Research Lab. (United States); R. M. Narayanan, The Pennsylvania State Univ. (United States)

\section{SESSION 7 APPLICATIONS AND EXPLOITATION}

9077 OR Superpixel segmentation using multiple SAR image products [9077-29]

M. M. Moya, M. W. Koch, D. N. Perkins, R. D. West, Sandia National Labs. (United States)

9077 OS Detection and tracking of personnel using a high-speed 94GHz surveillance radar [9077-30]

D. G. Macfarlane, D. A. Robertson, Univ. of St. Andrews (United Kingdom); B. Jones,

A. Clark, Ctr. for Applied Science and Technology (United Kingdom)

9077 OT Design considerations for quantum radar implementation [9077-31]

M. J. Brandsema, R. M. Narayanan, The Pennsylvania State Univ. (United States);

M. Lanzagorta, U.S. Naval Research Lab. (United States)

9077 OU Stepped-frequency nonlinear radar simulation [9077-32]

G. J. Mazzaro, The Citadel (United States); K. A. Gallagher, The Pennsylvania State Univ. (United States); A. F. Martone, U.S. Army Research Lab. (United States); R. M. Narayanan, The Pennsylvania State Univ. (United States)

9077 OV Determining snow depth using Ku-band interferometric synthetic aperture radar (InSAR) [9077-25]

J. R. Evans, F. A. Kruse, Naval Postgraduate School (United States); D. L. Bickel, Sandia National Labs. (United States); R. Dunkel, General Atomics Aeronautical Systems, Inc. (United States) 
9077 OW Medical radar considerations for detecting and monitoring Crohn's disease [9077-33] S. Smith, R. M. Narayanan, E. Messaris, The Pennsylvania State Univ. (United States)

9077 0X Development of a wearable microwave bladder monitor for the management and treatment of urinary incontinence [9077-34]

F. Krewer, F. Morgan, E. Jones, M. Glavin, M. O'Halloran, National Univ. of Ireland, Galway (Ireland)

9077 OY Development of anatomically and dielectrically accurate breast phantoms for microwave imaging applications [9077-35]

M. O'Halloran, S. Lohfeld, National Univ. of Ireland, Galway (Ireland); G. Ruvio, J. Browne, Dublin Institute of Technology (Ireland); F. Krewer, National Univ. of Ireland, Galway (Ireland); C. O. Ribeiro, V. C. Inacio Pita, R. C. Conceicao, Univ. de Lisboa (Portugal); E. Jones, M. Glavin, National Univ. of Ireland, Galway (Ireland)

$90770 Z$ Estimation of respiratory rhythm during night sleep using a bio-radar [9077-36]

A. Tataraidze, L. Anishchenko, M. Alekhin, Bauman Moscow State Technical Univ. (Russian Federation); L. Korostovtseva, Y. Sviryaev, Federal Almazov Medical Research Ctr. (Russian Federation)

907710 Simulation of holographic radar application in detection of breast fumors [9077-37] I. L. Alborova, L. N. Anishchenko, Bauman Moscow State Technical Univ. (Russian Federation)

907711 Comparison between UWB and CW radar sensors for breath activity monitoring [9077-38] S. Pisa, P. Bernardi, R. Cicchetti, R. Giusto, E. Pittella, E. Piuzzi, O. Testa, Univ. degli Studi di Roma La Sapienza (Italy)

907712 Fall detection and classifications based on time-scale radar signal characteristics [9077-39]

A. Gadde, M. G. Amin, Y. D. Zhang, F. Ahmad, Villanova Univ. (United States)

SESSION 9 RADAR MICRO-DOPPLER SIGNATURES I: JOINT SESSION WITH CONFERENCES 9077 AND 9082

907713 Performance bounds on micro-Doppler estimation and adaptive waveform design using OFDM signals [9077-40]

S. Sen, J. Barhen, C. W. Glover, Oak Ridge National Lab. (United States)

907714 Characterization of micro-Doppler radar signature of commercial wind turbines [9077-41] F. Kong, Y. Zhang, R. Palmer, The Univ. of Oklahoma (United States) and Advanced Radar Research Ctr. (United States)

907715 Micro-Doppler classification of riders and riderless horses [9077-42]

D. Tahmoush, U.S. Army Research Lab. (United States)

907716 Effect of wind turbine micro-Doppler on SAR and GMTI signatures [9077-43]

R. Bhalla, Leidos, Inc. (United States); H. Ling, The Univ. of Texas at Austin (United States) 
907717 Detection of small UAV helicopters using micro-Doppler [9077-44]

D. Tahmoush, U.S. Army Research Lab. (United States)

SESSION 10 RADAR MICRO-DOPPLER SIGNATURES II: JOINT SESSION WITH CONFERENCES 9077 AND 9082

907718 Software-defined radar and waveforms for studying micro-Doppler signatures [9077-45]

B. Liu, R. Chen, Ancortek Inc. (United States)

907719 Very low-phase noise, coherent 94GHz radar for micro-Doppler and vibrometry studies [9077-46]

D. A. Robertson, Univ. of St. Andrews (United Kingdom); G. M. Brooker, The Univ. of Sydney

(Australia); P. D. L. Beasley, QinetiQ Ltd. (United Kingdom)

9077 IA Comparative of signal processing techniques for micro-Doppler signature extraction with automotive radar systems [9077-47]

B. Rodriguez-Hervas, M. Maile, B. C. Flores, The Univ. of Texas at El Paso (United States) and Mercedes-Benz Research \& Development North America, Inc. (United States)

9077 1B Stationary and moving target shadow characteristics in synthetic aperture radar [9077-48] A. M. Raynal, D. L. Bickel, A. W. Doerry, Sandia National Labs. (United States)

9077 1C Extremely high-frequency micro-Doppler measurements of humans [9077-49]

A. S. Hedden, J. L. Silvious, C. R. Dietlein, U.S. Army Research Lab. (United States);

J. A. Green, U.S. Army Research Lab. (United States) and Univ. of Maryland (United States);

D. A. Wikner, U.S. Army Research Lab. (United States)

\section{SESSION 11 COMPRESSIVE SENSING FOR RADAR I: JOINT SESSION WITH 9077 AND 9109}

9077 ID SAR moving target imaging using sparse and low-rank decomposition [9077-50]

K.-Y. Ni, S. Rao, HRL Labs., LLC (United States)

9077 IE Lidar compressive sensing using chaotic waveform [9077-51]

B. Verdin, R. von Borries, The Univ. of Texas at El Paso (United States)

9077 IF Off-grid compressive sensing through-the-wall radar imaging [9077-52]

S. Xia, F. Liu, Delaware State Univ. (United States)

9077 IG Wideband aperture array using RF channelizers and massively parallel digital 2D IIR filterbank [9077-53]

A. Sengupta, A. Madanayake, The Univ. of Akron (United States); R. Gómez-García, Univ. de Alcalá (Spain); E. D. Engeberg, The Univ. of Akron (United States)

$9077 \mathrm{lH} \quad$ Signal processing techniques for stepped frequency ultra-wideband radar [9077-54] L. Nguyen, U.S. Army Research Lab. (United States) 
907711 Some comments on performance requirements for DMTI radar [9077-55]

A. W. Doerry, D. L. Bickel, A. M. Raynal, Sandia National Labs. (United States)

9077 1J Backprojection for GMTI processing [9077-56]

A. W. Doerry, Sandia National Labs. (United States)

9077 1K Correcting radar range measurements for atmospheric propagation effects [9077-57]

A. W. Doerry, Sandia National Labs. (United States)

9077 IL Digital synthesis of linear-FM chirp waveforms: comments on performance and enhancements [9077-58]

A. W. Doerry, Sandia National Labs. (United States); J. M. Andrews, S. M. Buskirk, General Atomics Aeronautical Systems, Inc. (United States)

9077 1M A novel approach in automatic estimation of rats' loco-motor activity [9077-59]

L. N. Anishchenko, S. I. Ivashov, I. A. Vasiliev, Bauman Moscow State Technical Univ.

(Russian Federation)

9077 iN Application of step-frequency radars in medicine [9077-60]

L. Anishchenko, M. Alekhin, A. Tataraidze, S. Ivashov, A. Bugaev, Bauman Moscow State Technical Univ. (Russian Federation); F. Soldovieri, Istituto per il Rilevamento Elettromagnetico dell'Ambiente, CNR (Italy)

907710 Distortion effects in a switch array UWB radar for time-lapse imaging of human heartbeats [9077-61]

S. Brovoll, T. Berger, $\varnothing$. Aardal, Norwegian Defence Research Establishment (Norway);

T. Lande, Univ. of Oslo (Norway); S.-E. Hamran, Norwegian Defence Research

Establishment (Norway) and Univ. of Oslo (Norway)

9077 1Q Radar measurements of moving objects around corners in a realistic scene [9077-63] T. Johansson, A. Örbom, A. Sume, J. Rahm, S. Nilsson, M. Herberthson, M. Gustafsson,

$\AA$. Andersson, Swedish Defence Research Agency (Sweden)

9077 is Power line characterization from an airborne data collection with a millimeter wave radar [9077-65]

D. S. Goshi, L. Q. Bui, Honeywell International Inc. (United States)

9077 IT Detection of exudates in fundus imagery using a constant false-alarm rate (CFAR) detector [9077-68]

M. Khanna, E. Kapoor, The Sinus Institute of Northern Virginia (United States)

Author Index 


\title{
Conference Committee
}

\author{
Symposium Chair
}

David A. Whelan, Boeing Defense, Space, and Security (United States)

Symposium Co-chair

Nils R. Sandell Jr., Strategic Technology Office, DARPA (United States)

Conference Chairs

Kenneth I. Ranney, U.S. Army Research Laboratory (United States)

Armin Doerry, Sandia National Laboratories (United States)

Conference Program Committee

Fauzia Ahmad, Villanova University (United States)

Moeness G. Amin, Villanova University (United States)

Joseph C. Deroba, U.S. Army CERDEC Intelligence and Information Warfare Directorate (United States)

Mark Govoni, U.S. Army CERDEC Intelligence and Information Warfare Directorate (United States)

Majeed Hayat, The University of New Mexico (United States)

Chandra Kambhamettu, University of Delaware (United States)

Seong-Hwoon Kim, Raytheon Space \& Airborne Systems (United States)

James L. Kurtz, University of Florida (United States)

Changzhi Li, Texas Tech University (United States)

Jenshan Lin, University of Florida (United States)

David G. Long, Brigham Young University (United States)

Jia-Jih Lu, General Atomics Aeronautical Systems, Inc. (United States)

Neeraj Magotra, Western New England University (United States)

Anthony F. Martone, U.S. Army Research Laboratory (United States)

Gregory J. Mazzaro, The Citadel (United States)

George J. Moussally, Mirage Systems (United States)

Ram M. Narayanan, The Pennsylvania State University (United States)

Lam H. Nguyen, U.S. Army Research Laboratory (United States)

Hector A. Ochoa, The University of Texas at Tyler (United States)

Ann M. Raynal, Sandia National Laboratories (United States)

Jerry L. Silvious, U.S. Army Research Laboratory (United States)

Brian Smith, U.S. Army Armament Research, Development and Engineering Center (United States)

David Tahmoush, U.S. Army Research Laboratory (United States)

Berenice Verdin, The University of Texas at El Paso (United States) 
Frank Yakos, SELEX Galileo, Inc. (United States)

Yan Zhang, The University of Oklahoma (United States)

\section{Session Chairs}

1 Phenomenology and Technology

Anthony F. Martone, U.S. Army Research Laboratory (United States)

2 Programs and Systems

Gregory J. Mazzaro, The Citadel (United States)

3 Algorithms and Processing I

Seong-Hwoon Kim, Raytheon Space \& Airborne Systems (United States)

4 Algorithms and Processing II

Jerry L. Silvious, U.S. Army Research Laboratory (United States)

$5 \quad$ Noise and Low-Probability of Intercept Radar

Yan Zhang, The University of Oklahoma (United States)

6 Multiple Apertures and MIMO

Mark A. Govoni, U.S. Army CERDEC Intelligence and Information Warfare Directorate (United States)

$7 \quad$ Applications and Exploitation

Ann M. Raynal, Sandia National Laboratories (United States)

8 Medical Application of Radar

Ram M. Narayanan, The Pennsylvania State University (United States)

9 Radar Micro-Doppler Signatures I: Joint Session with Conferences 9077 and 9082

Ram M. Narayanan, The Pennsylvania State University (United States)

10 Radar Micro-Doppler Signatures II: Joint Session with Conferences 9077 and 9082

David Tahmoush, U.S. Army Research Laboratory (United States)

11 Compressive Sensing for Radar I: Joint Session with 9077 and 9109

Lam H. Nguyen, U.S. Army Research Laboratory (United States) 